\title{
Recent advances in understanding/managing trigeminal
}

\section{neuralgia [version 1; peer review: 2 approved]}

\author{
Mark Obermann (iD)1,2
}

${ }^{1}$ Center for Neurology, Asklepios Hospitals Schildautal, 38723 Seesen, Germany

${ }^{2}$ Department of Neurology, University of Duisburg-Essen, Hufelandstr. 55, 45122 Essen, Germany

V1 First published: 17 Apr 2019, 8(F1000 Faculty Rev):505

https://doi.org/10.12688/f1000research.16092.1

Latest published: 17 Apr 2019, 8(F1000 Faculty Rev):505

https://doi.org/10.12688/f1000research.16092.1
Open Peer Review

Approval Status

1 2

version 1

17 Apr 2019

Faculty Reviews are review articles written by the prestigious Members of Faculty Opinions. The articles are commissioned and peer reviewed before publication to ensure that the final, published version is comprehensive and accessible. The reviewers who approved the final version are listed with their names and affiliations.

1. Anthony M. Kaufmann, University of

Manitoba, Winnipeg, Manitoba, Canada

2. Constantinus Politis, Catholic University

Leuven, Leuven, Belgium

Any comments on the article can be found at the end of the article.

\section{Keywords}

trigeminal neuralgia, facial pain, recent advances, pathophysiology, treatment options, future treatment 
Corresponding author: Mark Obermann (m.obermann@asklepios.com)

Author roles: Obermann M: Conceptualization, Data Curation, Methodology, Project Administration, Supervision, Validation, Visualization, Writing - Original Draft Preparation, Writing - Review \& Editing

Competing interests: The author has received scientific support, travel support and/or honoraria from Biogen Idec, Novartis, Sanofi/Genzyme, Eli Lilly, Pfizer, Teva, and Heel. He received research grants from Allergan, Electrocore, Heel, and the German Ministry for Education and Research (BMBF).

Grant information: The author(s) declared that no grants were involved in supporting this work.

Copyright: (c) 2019 Obermann M. This is an open access article distributed under the terms of the Creative Commons Attribution License , which permits unrestricted use, distribution, and reproduction in any medium, provided the original work is properly cited.

How to cite this article: Obermann $\mathrm{M}$. Recent advances in understanding/managing trigeminal neuralgia [version 1; peer review: 2 approved] F1000Research 2019, 8(F1000 Faculty Rev):505 https://doi.org/10.12688/f1000research.16092.1

First published: 17 Apr 2019, 8(F1000 Faculty Rev):505 https://doi.org/10.12688/f1000research.16092.1 


\section{Introduction}

Trigeminal neuralgia (TN) is defined by the International Headache Society as a "unilateral disorder characterized by brief electric shock-like pains, abrupt in onset and termination, and limited to the distribution of one or more divisions of the trigeminal nerve". The revised ICHD-III (International Classification of Headache Disorders, 3rd edition, beta version) classifies TN as classic (essential or idiopathic) TN without or with concomitant persistent facial pain ${ }^{1,2}$. TN caused by trauma, tumor, herpes zoster, or multiple sclerosis is classified as secondary painful trigeminal neuropathy. A slight hyperesthesia or hypoesthesia, either of which is often present, is now in line with the classic TN diagnosis ${ }^{2}$.

TN typically starts in the second or third branches of the trigeminal nerve ${ }^{2}$. An involvement of the ophthalmic nerve may be associated with other differential diagnoses such as severe unilateral neuralgiform headache attacks with conjunctival injection and tearing (SUNCT) and luckily is present in less than $5 \%$ of cases ${ }^{3}$. Typical TN attacks usually last between 1 second and a few seconds. TN may also occur in clusters of different duration and intensity lasting up to 2 minutes. The attack is followed by a short refractory period in many patients, during which a new attack cannot be evoked by further stimulation. In between paroxysms, patients are usually pain-free; however, in some patients, a dull, concomitant background pain may persist ${ }^{2}$. Pathophysiological mechanisms explaining this concomitant pain are missing, but it seems to be associated with a poor medical and surgical outcome ${ }^{5-8}$. Although many patients respond to first-line therapy initially, most treatment approaches tend to lose efficacy over time, so new and innovative treatment options are warranted. Many patients will receive surgery after their medical treatment failed, whereas others require medical treatment after the long-term efficacy of surgery slowly deteriorates.

\section{Quality of life}

Severe attacks may cause an inability to speak or eat. Many patients contemplate the constant fear of pain that may return at any time even between attacks ${ }^{9}$, which results in serious impairment of their individual daily function and their quality of life. Reduced measures of daily functioning, quality of life, well-being, sleep, mood, and overall health status correlated with pain severity ${ }^{10}$. In $34 \%$ of patients with $\mathrm{TN}$, even employment was impacted. Depression is quite frequent in this patient population. Moderate to severe pain was reported by up to two thirds of patients within the previous 24 hours $^{10}$. Owing to difficulties in properly assessing the burden of disease, a recent study evaluated the validity of a revised version of the Penn Facial Pain Scale (Penn-FPS-R), which focuses on the patients' health-related quality of life. The Penn-FPS was introduced as a supplement to the Brief Pain Inventory Pain Interference Index (BPI-PII) and was revised to include a total of 12 items with more TN-specific additions such as "biting and chewing", "self-care" (brushing the teeth, shaving, and so on), and "temperature change" (moving outside, air-condition effects, and so on). Besides the usefulness of the questionnaire, this study revealed a high burden of disease with an average mean pain of 6.85 (standard deviation of 2.34) on a 0 - to 10-point numerical rating scale despite adequate treatment attempts in the majority of included patients ${ }^{11}$.

\section{Prognostic factors}

A correct diagnosis is the paramount factor for adequate treatment and thus a good outcome. Differentiating trigeminal autonomic cephalalgias (for example, cluster headache, SUNCT, and paroxysmal hemicrania) and other craniofacial pain syndromes or persistent idiopathic facial pain is very important, as treatment is fundamentally different. Patients with firstdivision trigeminal pain only may have symptomatic TN (STN) (that is, due to multiple sclerosis or tumor) ${ }^{12}$, which is more difficult to treat ${ }^{13,14}$. Routine head imaging with magnetic resonance imaging (MRI) can detect structural causes in as many as $15 \%$ (95\% confidence interval [CI] 11-20\%) of patients excluding those with microvascular conflict. The blink reflex and other trigeminal reflex tests have a high accuracy to identify patients with STN. Five independent studies showed a pooled sensitivity of $94 \%$ (95\% CI 91-97\%) and a pooled specificity of $87 \%$ (95\% CI 77-93\%). Evoked potentials were unable to sufficiently distinguish classic TN from STN (pooled specificity $64 \%, 95 \%$ CI $56-71 \%$; pooled sensitivity $84 \%, 95 \%$ CI $73-92 \%)^{15,16}$.

MRI plays a major role in the pre-surgical assessment in order to determine the presence of microvascular conflict. Specificities and sensitivities are variable (specificity 29 to $93 \%$, sensitivity 52 to $100 \%$ ) between studies and this is probably related to different MRI sequences used in different investigations ${ }^{15,16}$. Moreover, a large imaging study of 135 patients with TN showed the presence of neurovascular conflict (NVC) on the symptomatic and the asymptomatic side (89\% versus $78 \%$, $P=0.014$; odds ratio $2.4,95 \%$ CI $1.2-4.8, P=0.017)$. Severe NVC was more frequent on the symptomatic side compared with the asymptomatic one $(53 \%$ versus $13 \%, P<0.001$; odds ratio $11.6,95 \%$ CI $4.7-28.9, P<0.001)$. The most common causes for severe neurovascular contact were arteries in $98 \%$ of cases ${ }^{17}$. NVC causing atrophy or displacement of the nerve (or both) was highly associated with pain on the symptomatic side of patients with classic $\mathrm{TN}$ in contrast to $\mathrm{NVC}$ in general, according to this study ${ }^{17}$. A more recent study reported that neurovascular contact with morphological changes to the nerve as detected by 3-Tesla MRI and male gender was associated with better outcome following microvascular decompression surgery $^{18}$. Excellent outcome and concomitant persistent pain, current age, or disease duration were not correlated ${ }^{18}$. Outcome after microvascular decompression surgery was only slightly worse; recurrence rates were $9.23 \%$ in the age group younger than 65 years and $13.33 \%$ in the group older than 65 years ${ }^{19}$. However, long-term outcome was determined by concomitant pain as these patients developed $\mathrm{TN}$ recurrence in $60.3 \%$ following microvascular decompression surgery whereas patients without concomitant pain did not show signs of recurrence in $91.8 \%$ within a mean follow-up period of 20.6 months $^{20}$. Depression and anxiety, along with a deterioration in quality of life, are common in patients with $\mathrm{TN}^{21}$. About $2 \%$ of patients with multiple sclerosis were reported to have symptoms similar to those of patients with $\mathrm{TN}^{3}$. TN commonly runs in families, but there have been reports of an increased risk in people living in 
the same household, which suggests that environmental factors may influence the disease ${ }^{22,23}$. Genetic variants of $\mathrm{TN}$ were also suggested in two investigated families: autosomal dominant in one family and autosomal recessive in the other ${ }^{24}$.

\section{Developing treatment options}

A novel substance finished its phase II trial last year with promising results. BIB074 (formerly known as CNV1014802, proposed name vixotrigine, formerly raxatrigine) is a new state-dependent sodium channel blocker with potency and selectivity of the $\mathrm{Na}_{\mathrm{v}} 1.7$ sodium channel over the different tested subtypes $\left(\mathrm{Na}_{\mathrm{v}} 1.1, \mathrm{Na}_{\mathrm{v}} 1.2, \mathrm{Na}_{\mathrm{v}} 1.3, \mathrm{Na}_{\mathrm{v}} 1.5, \mathrm{Na}_{\mathrm{v}} 1.6\right.$, and TTX-R) for the depolarized and resting states. Sodium channel blocking quantity increases in parallel to increased stimulation frequency of $\mathrm{Na}_{\mathrm{v}} 1.7$ and of $\mathrm{Na}_{\mathrm{v}} 1.2$ and $\mathrm{Na}_{\mathrm{v}}$ 1.6. BIB074 preferentially targets and inhibits higher frequencies $(10 \mathrm{~Hz}$ and more) induced during seizures or by noxious stimuli ${ }^{25}$.

A novel randomized withdrawal design was used in the phase II study in order to show its efficacy ${ }^{26}$. A 21-day open-label treatment period using BIB074 $150 \mathrm{mg}$ three times per day (tid) was followed by randomization into a double-blind treatment phase of 28 days with either placebo or BIB074 $150 \mathrm{mg}$ tid only in those patients who showed a successful treatment response within the final week ${ }^{27}$. The others were considered nonresponders and dropped out of the study in order to go back on their previous TN medication. Thirty percent or more reduction in pain severity as well as a $30 \%$ reduction in numbers of paroxysms relative to the run-in period was defined as treatment response. Sixty-seven patients were included in the study and $69 \%$ completed the open-label phase to enter the double-blind phase.

BIB074 was able to reduce the number of paroxysms and the overall pain severity in all primary and secondary outcomes but missed statistical significance in its primary endpoint. A reduction of the number of paroxysms by $60 \%$ compared with $12 \%$ for placebo was demonstrated, and pain severity decreased by $55 \%$ compared with $18 \%$ under placebo treatment. The primary endpoint was treatment failure rate of 33\% with BIB074 compared with $65 \%$ with placebo and a satisfactory separation of both conditions on the Kaplan-Meier time to relapse. BIB074 was well tolerated and no serious adverse events related to the drug were reported. The adverse event profile was comparable to that of placebo in the double-blind phase of the study ${ }^{27}$. The results are quite promising, but it should be remembered that the patient numbers were low and there was a short evaluation period, so this novel therapeutic option must prove its efficacy over time. A multicenter and international phase III study by Biogen is planned.

Botulinum neurotoxin type A (BoNT-A) was effective in the treatment of $\mathrm{TN}$ in recent studies. The pharmacological mechanism remains unresolved but includes the local release of anti-nociceptive neuropeptides such as glutamate, substance $\mathrm{P}$, and calcitonin gene-related peptide (CGRP) in order to reduce central and peripheral sensitization ${ }^{28}$. Significant symptom relief following BoNT-A injections was shown in a small uncontrolled clinical trial $(\mathrm{N}=13)$. BoNT-A was administered at a mean dose of 3.22 units $/ \mathrm{cm}^{2}$ subcutaneously directly in the painful area of the face. The treatment effect of BoNT-A slowly faded after 60 days $^{29}$. A randomized, placebo-controlled, double-blind study investigated 84 patients with classic TN treated with $25 \mathrm{U}$ or $75 \mathrm{U}$ of BoNT-A: placebo $(\mathrm{n}=28)$, BoNT-A $25 \mathrm{U}(\mathrm{n}=27)$, BoNT-A $75 \mathrm{U}(\mathrm{n}=29)$. The duration of the study was 8 weeks. Pain severity, efficacy, and side effects were the endpoints of the study. Significant reduction of pain was shown on a visual analogue scale with both the $25 \mathrm{U}$ and $75 \mathrm{U}$ groups compared with placebo after 1 week, which remained stable for the whole study period. Responders among the $25 \mathrm{U}$ group (70.4\%) and $75 \mathrm{U}$ group (86.2\%) were more common compared with placebo $(32.1 \%)$ at week 8 . No difference between the $25 \mathrm{U}$ and $75 \mathrm{U}$ groups was detectable. Patient Global Impression of Change (PGIC) showed that $66.7 \%$ (25 U group) and $75.9 \%$ (75 U group) of patients reported "much improved" or "very much improved" pain symptoms but that only $32.1 \%$ of the placebo patients stated this outcome. Only mild or moderate side effects were documented $^{30}$. The authors of a recent comprehensive metaanalysis showed a pooled reduction of -3.009 points on a 0 to 10 verbal rating scale $(95 \%$ CI -4.566 to $-1.453, P<0.001)$ after treatment with BoNT-A and confirmed moderate evidence for the efficacy of BoNT-A ${ }^{31}$. These promising findings will have to be confirmed by additional controlled clinical trials in order to recommend the use of BoNT-A for the treatment of $\mathrm{TN}^{32}$.

\section{Established medical treatment}

Pharmacological and surgical treatment options are numerous, widely used, and not seldom efficacious (Table 1). Medical therapy should be the first choice, and only after two failed treatment attempts may surgical interventions be considered in patients. Between 33 and $50 \%$ of patients may require surgical intervention at some point. No direct comparison studies between medical and surgical treatment exist. Active support group participation may help patients to better cope with their condition and stay compliant with medication ${ }^{33}$.

Carbamazepine (CBZ) (200-1200 mg/day) and oxcarbazepine (OXC) (600-1800 mg/day) should be considered first-line therapy, according to commonly accepted treatment guidelines ${ }^{15,16}$. Even though $\mathrm{CBZ}$ has stronger evidence ${ }^{34-37}$, OXC is generally considered to be better tolerated ${ }^{38}$. Second-line therapy includes add-on therapy with lamotrigine $(400 \mathrm{mg} / \text { day })^{39}$, change to lamotrigine monotherapy, or the use of baclofen $(40-80 \mathrm{mg} / \text { day })^{40}$.Pimozide $(4-12 \mathrm{mg} /$ day) is seldom in clinical use. Different antiepileptic drugs were investigated in open-label studies with small patient numbers. Efficacy was described for clonazepam, pregabalin, gabapentin, phenytoin, topiramate, valproate, and tocainide $(12 \mathrm{mg} / \text { day })^{41}$.

\section{Neuromodulation techniques}

Neuromodulation offers an alternative worth considering for patients whose neuropathy pain is refractory to pharmacotherapy. Central and peripheral neuromodulation are available, but the clinical evidence base is very limited. Options include electrical Gasserian (trigeminal) ganglion stimulation ${ }^{42}$, peripheral nerve stimulation ${ }^{43,44}$, and invasive motor cortex stimulation ${ }^{45}$ and 


\begin{tabular}{|c|c|}
\hline First line & $\begin{array}{l}\text { Carbamazepine (600-1200 mg/day) or } \\
\text { oxcarbazepine (600-1800 mg/day) }\end{array}$ \\
\hline Second line & $\begin{array}{l}\text { Add-on or switch to lamotrigine (400 mg/day) } \\
\text { Baclofen ( } 40-80 \mathrm{mg} / \text { day) } \\
\text { Pimozide (4-12 mg/day) }\end{array}$ \\
\hline Surgery & $\begin{array}{l}\text { Percutaneous procedures on the Gasserian ganglion } \\
\text { Percutaneous glycerol rhizolysis } \\
\text { Radiofrequency thermocoagulation } \\
\text { Balloon compression } \\
\text { Gamma knife radiosurgery } \\
\text { Microvascular decompression }\end{array}$ \\
\hline $\begin{array}{l}\text { Alternative medical } \\
\text { treatment options } \\
\text { (class III or IV) }\end{array}$ & $\begin{array}{l}\text { Pregabalin (150-600 mg/day) } \\
\text { Gabapentin (900-3600 mg/day) } \\
\text { Topiramate (100-400 mg/day) } \\
\text { Tocainide ( } 20 \text { mg/day) } \\
\text { Valproate (600-2400 mg/day) }\end{array}$ \\
\hline
\end{tabular}

non-invasive cortex stimulation ${ }^{46,47}$. Patient self-conducted motor cortex transcranial direct-current stimulation (tDCS) showed excellent efficacy on pain reduction in patients with classic $\mathrm{TN}$. Ten patients received daily stimulation over the course of 20 minutes for a total of 2 weeks with anodal $(1 \mathrm{~mA})$ or sham tDCS over the primary motor cortex (M1) in a double-blind, randomized, crossover design. Pain intensity was the primary outcome variable on a verbal rating scale (0-10). Anodal tDCS resulted in a $29 \%$ reduction of pain intensity after treatment $(P=0.0008)$. Reduction in attack frequency was also observed but did not reach statistical significance. No relevant adverse events were reported. Anodal tDCS over the course of two weeks may become a valuable treatment option for patients otherwise unresponsive to standard medical treatment ${ }^{8}$.

Repetitive transcranial magnetic stimulation (rTMS) is also a relatively novel technology introducing the possibility of testing the responsiveness of patients with trigeminal neuropathic pain to invasive epidural cortical stimulation. In 24 patients, TN was treated with daily $20-\mathrm{Hz}$ motor cortex stimulation over the course of five days. Ratings of pain decreased by $45 \%$ for at least 2 weeks $^{48}$. A different investigation included 12 patients who failed surgery with intractable $\mathrm{TN}$, out of which $58 \%$ reported more than $30 \%$ reduction of pain intensity following rTMS $^{49}$.

\section{Surgical treatment}

Medical treatment-refractory patients with a minimum of two adequately dosed recommended TN medications, including CBZ, are candidates for surgical treatment. The patients' symptoms, not any neuroimaging investigations, are the most relevant factor for this decision ${ }^{50}$. TN surgical management is either ablative (destructive) with the intentional destruction of sensory function of the trigeminal nerve or non-destructive with mere decompression of the trigeminal nerve and preservation of its normal function.
Percutaneous techniques to the Gasserian ganglion are all destructive and consist mainly of percutaneous glycerol rhizolysis, radiofrequency thermocoagulation, and balloon compression.Pain relief was reported by $90 \%$ of patients undergoing these procedures. Approximately 68 to $85 \%$ of patients remain pain-free after 1 year but this deteriorates to 54 to $64 \%$ after 3 years and only $50 \%$ are still pain-free after 5 years. Sensory loss $(50 \%)$ is the most common side effect with high impact on quality of life for these patients ${ }^{21}$, followed by dysesthesias $(6 \%)$, corneal numbness with risk of keratitis (4\%), and anesthesia dolorosa (4\%). Gasserian ganglion treatments are generally minor, overnight procedures with very low mortality $^{15,16}$.

Gamma knife surgery uses a focused radiation beam to sever the trigeminal root in the posterior fossa. Sixty-nine percent of patients were reported to remain pain-free 1 year after gamma knife surgery without additional medication. After 3 years, this was down to $52 \%$. Pain relief may require up to several weeks (mean of 1 month) in order to develop. Sensory complications were reported in $6 \%$ of patients with a delay of up to 6 months, including paraesthesias in 6 to $13 \%$, and facial numbness in 9 to $37 \%$ that may improve with time ${ }^{15,16}$. Quality of life improves by $88 \%{ }^{21}$. However, gamma knife surgery is quite expensive, limiting its more widespread usage. This makes it a treatment reserved for patients unfit to bear conventional surgery or with blood coagulation disease or medication (for example, warfarin).

The most sustained pain relief was reported following microvascular decompression surgery. Ninety percent of patients had initial pain relief. More than $80 \%$ were still pain-free 1 year after surgery and this fell to $75 \%$ after 3 years and $73 \%$ after 5 years. However, it is a major surgical intervention including craniotomy in the posterior fossa to reach the trigeminal nerve. Mortality rates range from 0.2 to $0.5 \%$ on average, and about $4 \%$ of 
patients have serious adverse events such as infarcts, hematomas, or cerebrospinal fluid leakage. The most frequent complications are aseptic meningitis (11\%), hearing loss (10\%), and sensory loss $(7 \%)^{15,16}$.

Recent studies focused on the long-term evaluation of different surgical treatments ${ }^{51,52}$ and the improvement of common surgical techniques ${ }^{53-55}$. A huge number of studies were conducted in this regard over the past several years, but most of them remain on a descriptive level unable to unveil evidence-based comparisons and therefore inspire only indirect recommendations. It remains to be determined what the right timing for surgical intervention is ${ }^{56}$. Some experts recommended early surgical referral of patients unresponsive to first-line medical treatments, whereas other experts require at least two different drugs (including CBZ) alone and in combination medical therapy before even considering surgery. Supporting final evidence for either of the two options is still missing. It seems reasonable to refer patients unresponsive to medical treatment for surgical intervention without a long delay.

\section{Conclusions}

Treatment of TN is still challenging, as individual responses to different therapeutic options may vary considerably. Only a few available therapy options have confirmed efficacy fulfilling current standards for evidence-based medicine. However, novel therapeutic options are on the rise; for the first time, substances are in clinical testing on larger patient populations specifically for this very disabling but rare disease. Outcome predictors and risk factors for treatment failure are being systematically assessed more and more so that an individual patient-guided treatment decision can be made. The continual effort by clinicians, researchers, and the pharmaceutical industry may soon provide therapeutic options that are more tolerable, more specific, and more efficient for patients with TN.

Grant information

The author(s) declared that no grants were involved in supporting this work.
1. Headache Classification Subcommittee of the International Headache Society: The International Classification of Headache Disorders: 2nd edition. Cephalalgia Int $J$ Headache. 2004; 24 Suppl 1: 9-160. PubMed Abstract

2. Headache Classification Committee of the International Headache Society (IHS): The International Classification of Headache Disorders, 3rd edition (beta version). Cephalalgia Int J Headache. 2013; 33(9): 629-808. PubMed Abstract | Publisher Full Text

3. de Simone R, Marano E, Brescia Morra V, et al:: A clinical comparison of trigeminal neuralgic pain in patients with and without underlying multiple sclerosis. Neurol Sci. 2005; 26 Suppl 2: s150-1. PubMed Abstract | Publisher Full Text

4. Maarbjerg S, Gozalov A, Olesen J, et al.: Trigeminal neuralgia--a prospective systematic study of clinical characteristics in 158 patients. Headache. 2014; 54(10): 1574-82.

PubMed Abstract | Publisher Full Text

5. Szapiro J Jr, Sindou M, Szapiro J: Prognostic Factors in Microvascular Decompression for Trigeminal Neuralgia. Neurosurgery. 1985; 17(6): 920-9. PubMed Abstract | Publisher Full Text

6. Obermann M, Yoon MS, Sensen K, et al:: Efficacy of pregabalin in the treatment of trigeminal neuralgia. Cephalalgia. 2008; 28(2): 174-81.

PubMed Abstract | Publisher Full Text

7. Sandell T, Eide PK: Effect of microvascular decompression in trigemina neuralgia patients with or without constant pain. Neurosurgery. 2008; $63(1)$ : 93-9; discussion 99-100. PubMed Abstract | Publisher Full Text

8. Hagenacker T, Bude V, Naegel S, et al:: Patient-conducted anodal transcranial direct current stimulation of the motor cortex alleviates pain in trigeminal neuralgia. $J$ Headache Pain. 2014; 15: 78

PubMed Abstract | Publisher Full Text | Free Full Text

9. Cheshire WP: :Trigeminal neuralgia feigns the terrorist. Cephalalgia. 2003; 23(3): 230.

PubMed Abstract | Publisher Full Text

10. Tölle T, Dukes E, Sadosky A: Patient Burden of Trigeminal Neuralgia: Results from a Cross-Sectional Survey of Health State Impairment and Treatment Patterns in Six European Countries. Pain Pract. 2006; 6(3): 153-60. PubMed Abstract | Publisher Full Text

11. F Symonds T, Randall JA, Hoffman DL, et al:: Measuring the impact of trigeminal neuralgia pain: The Penn Facial Pain Scale-Revised. J Pain Res. 2018; 11: 1067-73.

PubMed Abstract | Publisher Full Text | Free Full Text | F1000 Recommendation

12. Cohen AS, Matharu MS, Goadsby PJ: Short-lasting unilateral neuralgiform headache attacks with conjunctival injection and tearing (SUNCT) or cranial autonomic features (SUNA)--a prospective clinical study of SUNCT and SUNA.
Brain. 2006; 129(Pt 10): 2746-60.

PubMed Abstract | Publisher Full Text

13. Zebenholzer $\mathrm{K}$, Wöber $\mathrm{C}$, Vigl M, et al.: Facial pain and the second edition of the International Classification of Headache Disorders. Headache. 2006; 46(2): 259-63.

PubMed Abstract | Publisher Full Text

14. Zakrzewska JM: Diagnosis and Differential Diagnosis of Trigeminal Neuralgia. Clin J Pain. 2002; 18(1): 14-21.

PubMed Abstract | Publisher Full Text

15. Cruccu G, Gronseth G, Alksne J, et al.: AAN-EFNS guidelines on trigeminal neuralgia management. Eur J Neurol. 2008; 15(10): 1013-28. PubMed Abstract | Publisher Full Text

16. Gronseth G, Cruccu G, Alksne J, et al:: Practice parameter: The diagnostic evaluation and treatment of trigeminal neuralgia (an evidence-based review): report of the Quality Standards Subcommittee of the American Academy of Neurology and the European Federation of Neurological Societies. Neurology. 2008; 71(15): 1183-90.

PubMed Abstract | Publisher Full Text

17. $\mathrm{F}$ Maarbjerg S, Wolfram $\mathrm{F}$, Gozalov A, et al.: Significance of neurovascular contact in classical trigeminal neuralgia. Brain. 2015; 138(Pt 2): 311-9. PubMed Abstract | Publisher Full Text | F1000 Recommendation

18. F Heinskou TB, Rochat P, Maarbjerg S, et al.: Prognostic factors for outcome of microvascular decompression in trigeminal neuralgia: A prospective systematic study using independent assessors. Cephalalgia. 2019; 39(2): 197-208.

PubMed Abstract | Publisher Full Text | F1000 Recommendation

19. F Wallach J, Ho AL, Kim LH, et al:: Quantitative analysis of the safety and efficacy of microvascular decompression for patients with trigeminal neuralgia above and below 65 years of age. J Clin Neurosci. 2018; 55: 13-6. PubMed Abstract | F1000 Recommendation

20. F Wu A, Doshi T, Hung A, et al.: Immediate and Long-Term Outcomes of Microvascular Decompression for Mixed Trigeminal Neuralgia. World Neurosurg. 2018; 117: e300-e307. PubMed Abstract | F1000 Recommendation

21. Zakrzewska JM, Jassim S, Bulman SJ: A prospective, longitudinal study on patients with trigeminal neuralgia who underwent radiofrequency thermocoagulation of the Gasserian ganglion. Pain. 1999; 79(1): 51-8. PubMed Abstract | Publisher Full Text

22. Savica $\mathrm{R}$, Laganà $\mathrm{A}$, Siracusano $\mathrm{R}$, et al.: Idiopathic familial trigeminal neuralgia: a case report. Neurol Sci. 2007; 28(4): 196-8.

PubMed Abstract | Publisher Full Text

23. Smyth $\mathrm{P}$, Greenough $\mathrm{G}$, Stommel E: Familial trigeminal neuralgia: case reports 
and review of the literature. Headache. 2003; 43(8): 910-5.

PubMed Abstract | Publisher Full Text

24. F Cervera-Martinez C, Martinez-Manrique JJ, Revuelta-Gutierrez R: Surgical Management of Familial Trigeminal Neuralgia With Different Inheritance Patterns: A Case Report. Front Neurol. 2018; 9: 316.

PubMed Abstract | Publisher Full Text | Free Full Text | F1000 Recommendation

25. Keppel Hesselink JM: Moving targets in sodium channel blocker development: the case of raxatrigine: from a central NaV1.3 blocker via a peripheral NaV1.7 blocker to a less selective sodium channel blocker. J Med Therap. 2017; 1(1): 1-3. Publisher Full Text

26. Zakrzewska JM, Palmer J, Ettlin DA, et al:: Novel design for a phase lla placebocontrolled, double-blind randomized withdrawal study to evaluate the safety and efficacy of CNV1014802 in patients with trigeminal neuralgia. Trials. 2013; 14: 402 .

PubMed Abstract | Publisher Full Text | Free Full Text

27. Zakrzewska JM, Palmer J, Morisset V, et al:: Safety and efficacy of a Nav1.7 selective sodium channel blocker in patients with trigeminal neuralgia: a double-blind, placebo-controlled, randomised withdrawal phase 2a trial. Lancet Neurol. 2017; 16(4): 291-300.

PubMed Abstract

28. Aoki KR: Review of a proposed mechanism for the antinociceptive action of botulinum toxin type A. Neurotoxicology. 2005; 26(5): 785-93.

PubMed Abstract | Publisher Full Text

29. Piovesan EJ, Teive HG, Kowacs PA, et al:: An open study of botulinum-A toxin treatment of trigeminal neuralgia. Neurology. 2005; 65(8): 1306-8. PubMed Abstract | Publisher Full Text

30. F Zhang $\mathrm{H}$, Lian $\mathrm{Y}, \mathrm{Ma} \mathrm{Y}$, et al:: Two doses of botulinum toxin type $\mathbf{A}$ for the treatment of trigeminal neuralgia: observation of therapeutic effect from a randomized, double-blind, placebo-controlled trial. J Headache Pain. 2014; 15: 65. PubMed Abstract | Publisher Full Text | Free Full Text | F1000 Recommendation

31. F Fischoff DK, Spivakovsky S: Botulinum toxin for facial neuralgia. Evid Based Dent. 2018; 19(2): 57-8.

PubMed Abstract | Publisher Full Text | F1000 Recommendation

32. Burmeister $\mathrm{J}$, Holle $\mathrm{D}$, Bock $\mathrm{E}$, et al.: Botulinum neurotoxin type $\mathbf{A}$ in the treatment of classical Trigeminal Neuralgia (BoTN): study protocol for a randomized controlled trial. Trials. 2015; 16:550. PubMed Abstract | Publisher Full Text | Free Full Text

33. Zakrzewska JM, Jorns TP, Spatz A: Patient led conferences--who attends, are their expectations met and do they vary in three different countries? Eur $J$ Pain. 2009; 13(5): 486-91. PubMed Abstract | Publisher Full Text

34. Campbell FG, Graham JG, Zilkha KJ: Clinical trial of carbazepine (tegretol) in trigeminal neuralgia. J Neurol Neurosurg Psychiatr. 1966; 29(3): 265-7. PubMed Abstract | Publisher Full Text | Free Full Text

35. Killian JM, Fromm GH: Carbamazepine in the treatment of neuralgia. Use of side effects. Arch Neurol. 1968; 19(2): 129-136.

PubMed Abstract | Publisher Full Text

36. Nicol CF: A four year double-blind study of tegretol in facial pain. Headache. 1969; 9(1): 54-7.

PubMed Abstract | Publisher Full Text

37. Rockliff BW, Davis EH: Controlled sequential trials of carbamazepine in trigeminal neuralgia. Arch Neurol. 1966; 15(2): 129-36. PubMed Abstract | Publisher Full Text

38. Beydoun A: Safety and efficacy of oxcarbazepine: results of randomized, double-blind trials. Pharmacotherapy. 2000; 20(8 Pt 2): 152S-158S. PubMed Abstract | Publisher Full Text

39. Zakrzewska JM, Chaudhry Z, Nurmikko TJ, et al.: Lamotrigine (lamictal) in refractory trigeminal neuralgia: results from a double-blind placebo controlled crossover trial. Pain. 1997; 73(2): 223-30. PubMed Abstract | Publisher Full Text

40. Fromm GH, Terrence CF, Chattha AS: Baclofen in the treatment of trigeminal neuralgia: double-blind study and long-term follow-up. Ann Neurol. 1984; 15(3): 240-4.

PubMed Abstract | Publisher Full Text
41. Lindström $P$, Lindblom $U$ : The analgesic effect of tocainide in trigeminal neuralgia. Pain. 1987; 28(1): 45-50.

PubMed Abstract | Publisher Full Text

42. F Kustermans L, Van Buyten JP, Smet I, et al.: Stimulation of the Gasserian ganglion in the treatment of refractory trigeminal neuropathy. J Craniomaxillofac Surg. 2017; 45(1): 39-46.

PubMed Abstract | F1000 Recommendation

43. F Jakobs M, Unterberg A, Treede RD, et al:: Subcutaneous trigeminal nerve field stimulation for refractory trigeminal pain: a cohort analysis. Acta Neurochir (Wien). 2016; 158(9): 1767-74.

PubMed Abstract | Publisher Full Text | F1000 Recommendation

44. F Klein J, Sandi-Gahun S, Schackert G, et al:: Peripheral nerve field stimulation for trigeminal neuralgia, trigeminal neuropathic pain, and persistent idiopathic facial pain. Cephalalgia. 2016; 36(5): 445-53. PubMed Abstract | Publisher Full Text | F1000 Recommendation

45. F Kolodziej MA, Hellwig D, Nimsky C, et al:: Treatment of Centra Deafferentation and Trigeminal Neuropathic Pain by Motor Cortex Stimulation: Report of a Series of 20 Patients. J Neurol Surg A Cent Eur Neurosurg. 2016; 77(1): 52-8.

PubMed Abstract | Publisher Full Text | F1000 Recommendation

46. Antal A, Terney D, Kühnl S, et al.: Anodal transcranial direct current stimulation of the motor cortex ameliorates chronic pain and reduces short intracortical inhibition. J Pain Symptom Manage. 2010; 39(5): 890-903. PubMed Abstract

47. F Hodaj H, Alibeu JP, Payen JF, et al:: Treatment of Chronic Facial Pain Including Cluster Headache by Repetitive Transcranial Magnetic Stimulation of the Motor Cortex With Maintenance Sessions: A Naturalistic Study. Brain Stimul. 2015; 8(4): 801-7.

PubMed Abstract | F1000 Recommendation

48. Khedr EM, Kotb $\mathrm{H}$, Kamel NF, et al:: Longlasting antalgic effects of daily sessions of repetitive transcranial magnetic stimulation in central and peripheral neuropathic pain. J Neurol Neurosurg Psychiatr. 2005; 76(6): 833-8. PubMed Abstract | Publisher Full Text | Free Full Text

49. Lefaucheur JP, Drouot X, Menard-Lefaucheur I, et al:: Neurogenic pain relief by repetitive transcranial magnetic cortical stimulation depends on the origin and the site of pain. J Neurol Neurosurg Psychiatr. 2004; 75(4): 612-6. PubMed Abstract | Publisher Full Text | Free Full Text

50. Cheshire WP: Can MRI distinguish injurious from innocuous trigeminal neurovascular contact? J Neurol Neurosurg Psychiatr. 2005; 76(11): 1470-1. PubMed Abstract | Publisher Full Text | Free Full Text

51. Kabatas S, Karasu A, Civelek E, et al:: Microvascular decompression as a surgical management for trigeminal neuralgia: Long-term follow-up and review of the literature. Neurosurg Rev. 2009; 32(1): 87-93; discussion 93-4. PubMed Abstract | Publisher Full Text

52. Little AS, Shetter AG, Shetter ME, et al.: Long-term pain response and quality of life in patients with typical trigeminal neuralgia treated with gamma knife stereotactic radiosurgery. Neurosurgery. 2008; 63(5): 915-23; discussion 923-4. PubMed Abstract | Publisher Full Text

53. Sindou M, Leston JM, Decullier E, et al.: Microvascular decompression for trigeminal neuralgia: the importance of a noncompressive technique--KaplanMeier analysis in a consecutive series of $\mathbf{3 3 0}$ patients. Neurosurgery. 2008; 63(4 Suppl 2): 341-50; discussion 350-1. PubMed Abstract | Publisher Full Text

54. Kanpolat $\mathrm{Y}$, Kahilogullari G, Ugur HC, et al:: Computed tomography-guided percutaneous trigeminal tractotomy-nucleotomy. Neurosurgery. 2008; 63(1 Suppl 1): ONS147-53; discussion ONS153-5. PubMed Abstract

55. Tatli M, Sindou M: Anatomoradiological landmarks for accuracy of radiofrequency thermorhizotomy in the treatment of trigeminal neuralgia. Neurosurgery. 2008; 63(1 Suppl 1): ONS129-37; discussion ONS137-8. PubMed Abstract

56. Spatz AL, Zakrzewska JM, Kay EJ: Decision analysis of medical and surgical treatments for trigeminal neuralgia: how patient evaluations of benefits and risks affect the utility of treatment decisions. Pain. 2007; 131(3): 302-10. PubMed Abstract | Publisher Full Text 


\section{Open Peer Review}

\section{Current Peer Review Status:}

\section{Editorial Note on the Review Process}

Faculty Reviews are review articles written by the prestigious Members of Faculty Opinions. The articles are commissioned and peer reviewed before publication to ensure that the final, published version is comprehensive and accessible. The reviewers who approved the final version are listed with their names and affiliations.

\section{The reviewers who approved this article are:}

\section{Version 1}

\section{Constantinus Politis}

OMFS-IMPATH Research Group, Department of Imaging and Pathology, Faculty of Medicine, Catholic University Leuven, Leuven, Belgium

Competing Interests: No competing interests were disclosed.

\section{Anthony M. Kaufmann}

Section of Neurosurgery, Department of Surgery, University of Manitoba, Winnipeg, Manitoba, Canada

Competing Interests: No competing interests were disclosed.

The benefits of publishing with F1000Research:

- Your article is published within days, with no editorial bias

- You can publish traditional articles, null/negative results, case reports, data notes and more

- The peer review process is transparent and collaborative

- Your article is indexed in PubMed after passing peer review

- Dedicated customer support at every stage

For pre-submission enquiries, contact research@f1000.com 